\title{
Implementasi Multimedia Interaktif Pengenalan Alphabet Berbahasa Inggris Menggunakan Augmented Reality Untuk Tk/Ra Mardhotillah
}

\author{
Adam Rizki Fadhlurahman ${ }^{a}$, \\ ${ }^{a}$ Politeknik Negeri Media Kreatif, Jakarta \\ ${ }^{b}$ Politeknik Negeri Media Kreatif, Jakarta
}

\section{INFORMASI ARTIKEL}

Sejarah Artikel:

Diterima Redaksi: 29 April 2021

Diterbitkan Online: 31 Juli 2021

\section{KATA KUNCI \\ Alphabet, Aplikasi, Augmented Reality, Gadget.}

\section{KORESPONDENSI}

sarist@ polimedia.ac.id

\section{A B S T R A C T}

\begin{abstract}
Alphabet merupakan salah satu pelajaran yang paling dasar untuk anak prasekolah atau anak usia dini. Orang tua seharusnya memberikan media pembelajaran untuk anak sesuai dengan perkembangannya. Karena, anak - anak usia dini pada zaman sekarang sudah pandai dalam menggunakan gadget. Dengan adanya media pembelajaran menggunakan Aplikasi pengenalan alphabet berbasis Augmented Reality yang didalamnya terdapat objek 2D untuk menarik minat anakanak di TK/RA Mardhotillah ini dan juga dapat memudahkan mereka untuk lebih mengenal huruf alphabet dalam pelafalan bahasa inggris. Perancangan ini dilakukan dengan harapan supaya anakanak dapat belajar mengenal alphabet melalui media interaktif dengan visualisasi dan konten yang menarik untuk perkembangan cara belajar mereka. Alphabet merupakan salah satu pelajaran yang paling dasar untuk anak prasekolah atau anak usia dini. Orang tua seharusnya memberikan media pembelajaran untuk anak sesuai dengan perkembangannya. Karena, anak - anak usia dini pada zaman sekarang sudah pandai dalam menggunakan gadget. Dengan adanya media pembelajaran menggunakan Aplikasi pengenalan alphabet berbasis Augmented Reality yang didalamnya terdapat objek 2D untuk menarik minat anak-anak di TK/RA Mardhotillah ini dan juga dapat memudahkan mereka untuk lebih mengenal huruf alphabet dalam pelafalan bahasa inggris. Perancangan ini dilakukan dengan harapan supaya anak-anak dapat belajar mengenal alphabet melalui media interaktif dengan visualisasi dan konten yang menarik untuk perkembangan cara belajar mereka.
\end{abstract}

\section{PENDAHULUAN}

Menurut C. Asri. 2005 pada Abdurakhman Belajar ialah pergantian yang relatif permanen dalam sikap ataupun kemampuan sebagai hasil dari pengalaman ataupun latihan yang diperkuat. Belajar ialah akibat terdapat adanya interaksi antara stimulus serta respon, seseorang dianggap sudah belajar sesuatu bila ia dapat menampilkan perubahan perilakunya. bagi teori ini, dalam belajar yang berarti merupakan input yang berbentuk stimulus serta output yang berupa respon.

Menurut Musthofa (2018), Pendidikan untuk anak umur dini, salah satu tata cara pendidikan anak ialah pendidikan yang memakai Tata cara Sentra ataupun Beyond Centra And Circle Time (BCCT) yang dirancang buat penuhi kebutuhan belajar sembari bermain untuk anak umur dini yang berorientasi bermain, belajar sembari bermain serta bermain sembari belajar.

Sesuai dari hasil wawancara kepada Ummi Tuti Hairiyah selaku kepala sekolah TK/RA Mardhotillah mengatakan bahwa "
Metode pembelajaran bermain pendekatan sentra sangat minim, kendala yg dihadapi justru malah guru lebih santai , anak-anak lebih menikmati belajar sambil bermain didalam kelas, tetapi kami belum memiliki media pembelajaran yang mengikuti perkembangan zaman seperti memakai aplikasi Augmented Reality sebagai media pembelajarannya, curriculum bahasa inggris di tk sendiri tidak spesifik ke pembelajaran alphabet saja, melainkan tentang pengenalan bahasa inggris, jadi materi yg diberikan guru bisa bermacam-macam atau netral. Dan sesuai dengan proker tahun ini kami ingin membuat pembelajaran pengenalan alphabet dalam Bahasa inggris dengan bekerjasama dengan instansi terkait, tetapi tertunda dengan adanya pandemi. Pihak sekolah sangat senang jika mas adam mau menghibahkan karyanya berupa booklet yang mencantumkan logo Yayasan kami serta aplikasi untuk digunakan guru dalam mengajar.

Bahasa Inggris ialah bahasa internasional yang lumayan berarti buat dipelajari pada masa globalisasi. Dikala ini bahasa Inggris sudah dianjurkan pada kanak- kanak umur dini. Berartinya stimulasi pembelajaran anak semenjak umur dini didukung oleh hasil riset yang melaporkan kalau pada usia 4 tahun, anak sudah menggapai setengah dari keahlian kecerdasannya, serta pada usia 
8 tahun sudah menggapai $80 \%$. Sehabis usia 8 tahun, tanpa memandang wujud pendidikannya serta area yang diperoleh, keahlian kecerdasan anak cuma bisa diganti sebanyak $20 \%$. Tetapi kecenderungan pola belajar anak yang lebih suka bermain pula sangat pengaruhi, sehingga pendidikan secara teoritis saja kurang maksimal buat pendidikan Bahasa Inggris pada anak.

Diba Artsiyanti (2002) mengatakan bahwa kesulitan anak dalam mempelajari Bahasa Inggris disebabkan karena Bahasa Inggris bukan merupakan bahasa mereka, sehingga mereka tidak terbiasa mendengar atau mengucapkan pelafalan dalam Bahasa Inggris. Oleh karena itu diperlukan media untuk membantu anakanak dalam belajar Bahasa Inggris.

Sesuai dengan perkembangan zaman, pengaruh penggunaan multimedia dalam proses pembelajaran pada siswa. Berkenaan dengan pembelajaran kosakata yang menguji pengaruh penggunaan media audio visual terhadap kosakata anak. Setelah dilakukan ujicoba terhadap anak-anak di Tk Nurul Huda terhadap peningkatan pembelajaran kosakata dasar dengan menggunakan media gambar dan hasilnya menunjukkan bahwa media gambar berpengaruh signifikan terhadap peningkatan pembelajaran kosakata pada anak-anak. Berdasarkan hasil penelitian di atas, dapat disimpulkan bahwa penggunaan multimedia yang merupakan salah satu media audiovisual dapat berpengaruh terhadap kemampuan berbahasa pada anak seperti kemampuan berbicara, dan meningkatkan kosakata siswa.(2002)

Berdasarkan uraian pada latar belakang yang telah diajukan, maka permasalahan yang akan dikaji dalam tugas akhir ialah "Implementasi Multimedia Interaktif Pengenalan Alphabet Berbahasa Inggris Menggunakan Augmented Reality Untuk TK/RA Mardhotillah " dengan membuat media pembelajaran pengenalan alphabet berbahasa inggris dengan objek yang dapat memberikan informasi mengenai pengenalan alphabet.

\section{TINJAUAN PUSTAKA}

\subsection{Pembelajaran Alphabet}

Menurut Sujarnoto pada (2015) pembelajaran dalam memperkenalkan alfabet dalam perkembanganya mengalami perubahan. Dulu seseorang pendidik menghadirkan alfabet dengan mendekte huruf satu persatu dapat dikatakan cuma memahami serta menguasai alfabet saja. Jadi alfabet diajarkan secara spesial dalam modul pendidikan. Tetapi menghadirkan alfabet dikala ini dalam pendidikan kurikulum 2013 lewat selingan- selingan tema yang dianjurkan. Sehingga proses belajar dalam menghadirkan alfabet disetiap modul pelajaran yang di informasikan semacam menguasai suatu objek.

Menurut Salpariansi (2018) "alfabet adalah satu set huruf yang digunakan dalam bahasa tulisan". Mengenal huruf-huruf ini merupakan modal dasar bagi anak-anak dalam membaca dan menulis. Memahami alfabet sejak dini dapat menjadikan anak bisa membaca dan menulis sehingga dapat mandiri dalam mencari pengetahuan dan wawasan, tatacara berbahasa, mengembangkan pemikiran, dapat mencerdaskan intelektual, dan lain-lain

Dalam ilmu komputer, pengertian aplikasi merupakan suatu perangkat lunak atau program komputer yang beroperasi pada sistem tertentu yang di ciptakan dan dikembangkan untuk melakukan perintah tertentu. Istilah aplikasi diambil dari Bahasa inggris "application" yang diartikan penerapan atau penggunaan, secara harfiah, aplikasi merupakan suatu penerapan perangkat lunak yang dikembangkan untuk tujuan melakukan tugas-tugas tertentu.

\subsection{Augmented Reality}

Augmented Reality adalah istilah untuk lingkungan yang menggabungkan dunia nyata dan dunia virtual yang dibuat oleh komputer sehingga batas antara keduanya menjadi sangat tipis. Sistem ini lebih dekat kepada lingkungan nyata. Dengan teknologi Augmented Reality, lingkungan nyata disekitar akan dapat berinteraksi dalam bentuk digital. Infromasi tentang objek dan lingkungan sekitar dapat ditambahkan ke dalam sistem Augmented Reality yang kemudian akan ditampilkan pada layar dunia nyata secara real-time (waktu nyata) seolah-olah informasi tersebut nyata. Augmented Reality memiliki banyak potensi di dalam industry dan penelitian secara akademis, Pernyataan ini menurut candra,A (2014) pada Ichsan (2018)

Menurut Azuma pada Ichsan (2018) mendefinisikan Augmented Reality sebagai penggabungan benda-benda nyata dan maya di lingkungan nyata, berjalan secara interaktif dalam waktu nyata, dan terdapat integrasi antar benda dalam tiga dimensi, yaitu benda maya terintegrasi dalam dunia nyata. Penggabungan benda nyata dan maya dimungkinkan dengan teknologi tampilan yang sesuai, interaktivitas dimungkinkan melalui perangkat- perangkat input tertentu, dan integrasi yang baik memerlukan penjejakan yang efektif. Bidang-bidang yang menerapkan teknologi Augmented Reality adalah :

1. Bidang pemasaran digunakan untuk mempromosikan barang atau jasa dengan brosur virtual yang memberikan informasi lengkap secara tiga dimensi, sehingga barang atau jasa yg ditawarkan dapat dilihat secara jelas.

2. Bidang pendidikan digunakan untuk proses belajar mengajar yang dapat memberikan efek memudahkan dalam menjelaskan suatu objek

3. Bidang desain teknologi digunakan untuk menampilkan hasil desain secara 3D dan nyata yg akan diperlihatkan kepada klien.

\subsection{Aplikasi Berbasis Android}

Android ialah sistem pembedahan mobile. Android tidak membagi perbedaan antara aplikasi inti dengan aplikasi pihak ketiga. Application Programming Interface( API) yang disediakan menawarkan akses ke hardware, ataupun datadata ponsel sekalipun, ataupun informasi sistem sendiri. Apalagi pengguna bisa menghapus aplikasi inti serta menggantikannya dengan aplikasi pihak ketiga. Pernyataan ini menurut (Nazruddin, 2011), Pada Sariyun tentang Jurnal Teknologi informasi Dinamik (2015).

Aplikasi merupakan pelaksanaan dari rancang sistem yang mencerna informasi dengan memakai ketentuan ataupun syarat 
bahasa pemprograman tertentu. Aplikasi merupakan salah satu program computer yang terbuat buat mengerjakan serta melakukan tugas spesial dari pengguna. Secara sebutan aplikasi merupakan program siap gunakan yang diciptakan untuk melakukan sesuatu fungsi untuk pengguna ataupun aplikasi yang lain serta bisa digunakan oleh target yang dituju. Contoh fitur lunak aplikasi merupakan pengolah kata, lembar kerja serta pemutar media.

\section{HASIL DAN PEMBAHASAN}

\subsection{Profil Objek Penelitian}

TK/RA Mardhotillah adalah sekolah TK Islam yang berada Jl. Telaga (Depan Setu Pedongkelan) RT. 13/09 No. 36, Pekayon, Pasar Rebo. TK ini memiliki metode belajar sambil bermain dan tadabur alam \& bercerita. Dengan kurikulum didalamnya yg spesifik dengan pelajaran islamik, tetapi sama juga seperti TK yg lainnya, Tk ini sudah tentu memiliki kurikulum Membaca, Menulis, Berhitung dan ada juga pengenalan dasar Bahasa Ingris. Tk ini memiliki klasifikasi kelas sesuai dengan usia anak . Dan TK/RA Mardhotillah ini juga memiliki ekstrakulikuler yg dapat anak-anak ikuti sesuai dengan minatnya.

\subsection{Metode Pembelajaran Yang Sedang Berjalan}

Pada saat ini metode pembelajaran yang digunakan di sekolah TK/RA Mardhotillah sudah tidak menggunakan metode konvesional, melainkan dengan metode pembelajaran sentra, yang dimana guru membebaskan anak muridnya untuk bereksplorasi disetiap pembelajaran yang diberikan. Tetapi pembelajaran masih dengan berbasis media cetak dan belum menggunakan media interaktif seperti aplikasi pendukung.

\subsection{Perancangan Sistem}

\subsubsection{Use Case Diagram}

"Use Case Diagram adalah sesuatu atau proses merepresentasikan hal-hal yang dapat dilakukan oleh aktor dalam menyelesaikan sebuah pekerjaan." (Mamed Rofendy Manalu, 2015). Use case mendeskripsikan sebuah interaksi antara satu atau lebih aktor dengan sistem informasi yang akan dibuat. Secara kasar, use case digunakan untuk mengetahui fungsi apa saja yang ada di dalam sebuah sistem dan siapa saja yang berhak menggunakan fungsi-fungsi tersebut." Use case diagram menggambarkan sebuah interaksi antara satu atau lebih aktor dengan sistem informasi yang akan dibuat. Use case digunakan untuk mengetahui fungsi apa saja yang ada di dalam sebuah sistem dan siapa saja yang berhak menggunakan fungsi-fungsi tersebut.

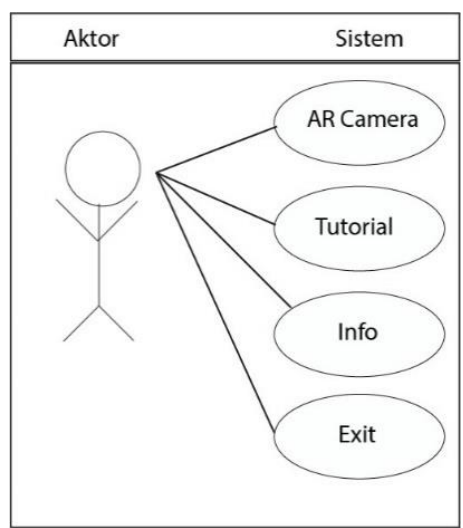

Gambar 3.1 Use Case Diagram

Pada saat aktor memilih tombol AR Camera, sistem akan merespon menampilkan layar kamera $\mathrm{AR}$, disini aktor dapat mengarahkan kamera pada marker yang sudah disediakan didalam booklet. Saat aktor memilih tombol tutorial, sistem akan menampilkan cara petunjuk penggunaan aplikasi. Saat aktor memilih tombol info, maka sistem akan menampilkan informasi yang tentang aplikasi tersebut. Saat aktor memilih tombol exit maka sistem akan keluar dari aplikasi.

\subsubsection{Activity Diagram}

Menurut Rosa dalam jurnal (Sari dan David) mengungkapkan : "Activity Diagram menggambarkan work flow (aliran kerja) atau aktivitas dari sebuah sistem atau proses bisnis. Yang perlu diperhatikan disini adalah bahwa diagram aktivitas menggambarkan aktivitas sistem bukan apa yang dilakukan aktor, jadi aktivitas dapat dilakukan oleh sistem. Activity Diagram menggambarkan workflow (aliran kerja) atau aktivitas dari sebuah sistem atau proses bisnis.

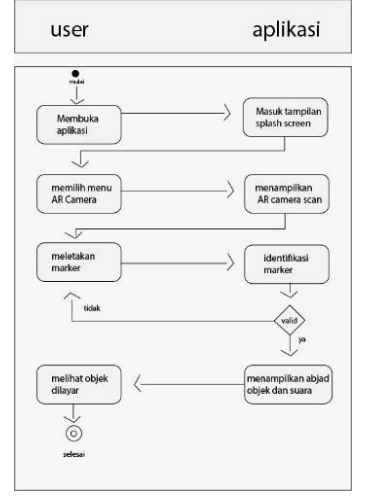

Gambar 3.2 Activity diagram Augmented Reality

\subsubsection{Class Diagram}

Merupakan hubungan antar kelas dan penjelasan detail tiap-tiap kelas di dalam model desain dari suatu sistem, juga memperlihatkan aturan-aturan dan tanggung jawab entitas yang menentukan perilaku sistem. Class Diagram juga menunjukkan atribut-atribut dan operasi-operasi dari sebuah kelas dan constraint yang berhubungan dengan objek yang dikoneksikan. 

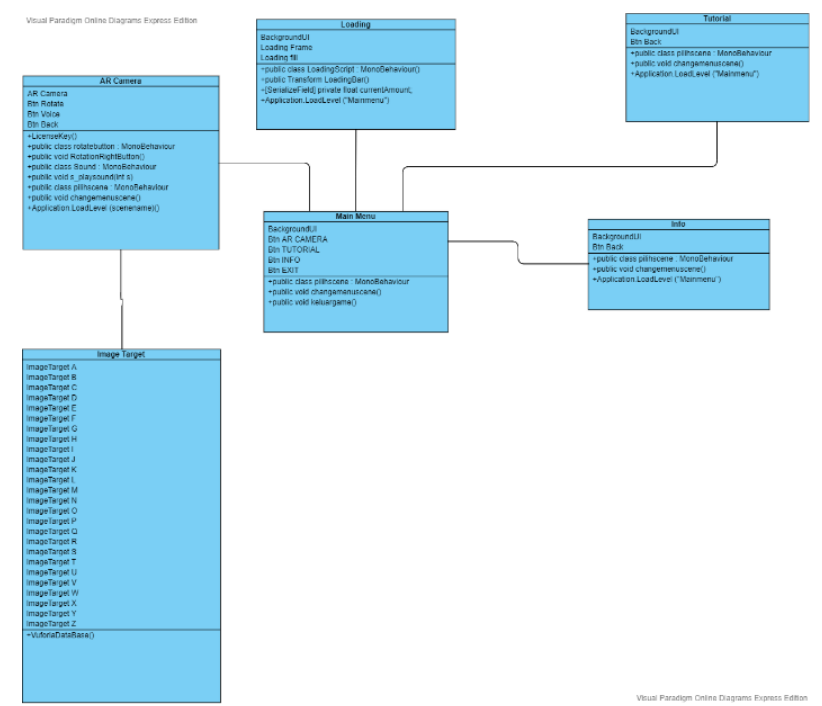

Gambar 3.3 Class Diagram

\section{HASIL DAN PEMBAHASAN}

\subsection{Implementasi Sistem}

Implementasi sistem adalah tahap dimana penerapan sistem yang akan dilakukan jika sistem disetujui, termasuk program yang telah dibuat pada tahap perancangan sistem supaya siap untuk dioperasikan.

\subsubsection{Tampilan Menu Utama}

Tampilan yang muncul setelah Splash Screen, ialah halaman Menu Utama, pada halaman ini terdapat button yang berguna untuk menghubungkan ke halaman lainnya.

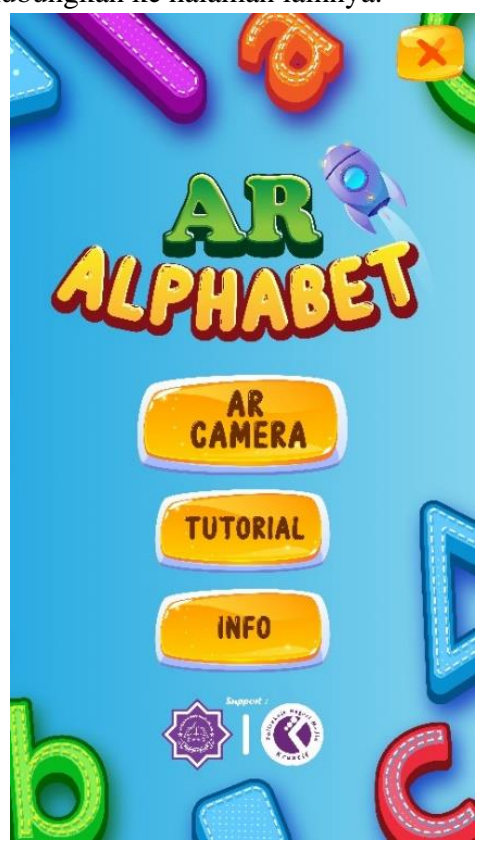

Gambar 4.1 Tampilan Main Menu

\subsubsection{Tampilan AR Camera}

Tampilan ini merupakan tampilan inti dari aplikasi "AR Alphabet", karena tampiln ini akan memperlihatkan huruf alphabet \& objek sebagai media pembelajaran, dan pada tampilan ini juga terdapat button "Voice" untuk mendengaran secara langsung pengejaan huruf \& objek yang ditampilan.

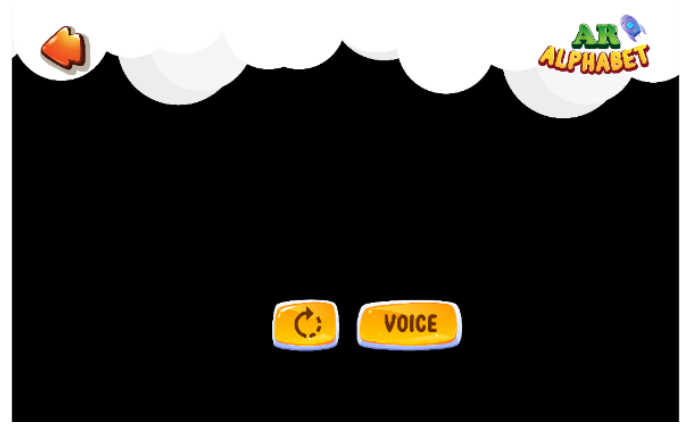

Gambar 4.2 Tampilan AR Camera

\subsubsection{Tampilan Cover Booklet}

Gambar di bawah ini merupakan cover pada booklet yang berisi marker tentang pengenalan huruf alphabet dan objeknya.

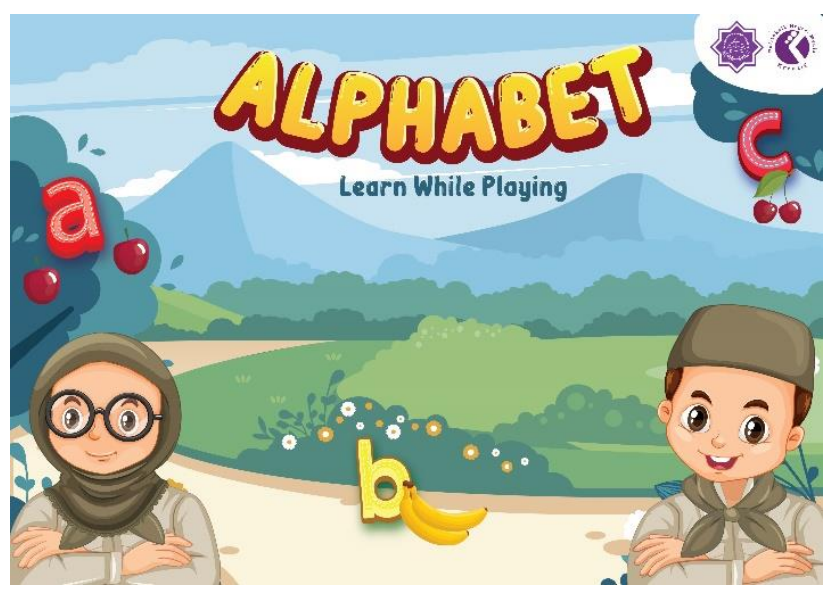

Gambar 4.3 Tampilan Cover Booklet

\subsection{Pengujian Sistem}

Pengujian Sistem merupakan tahapan uji coba dalam menjalankan aplikasi yang telah di import ke dalam smartphone. Untuk menguji aplikasi ini ialah dengan cara menggunakan empat buah smartphone dengan versi operasi sistem yang berbeda. Pada uji coba aplikasi ini dilakukan berulang kali untuk mengetahui masalah yag terjadi pada aplikasi, apabila ada masalah yang terjadi pada saat menguji cobanya, maka akan dicari solusi dan akan segera diperbaiki sampai aplikasi dapat dijalankan dan berfungsi dengan baik dan benar. Berikut ini adalah spesifikasi yang digunakan untuk uji coba aplikasi : 


\begin{tabular}{|c|c|c|c|c|c|}
\hline $\begin{array}{l}\text { Perangkat } \\
\text { Smartphone }\end{array}$ & Procccessor & RAM & $\begin{array}{l}\text { Resolusi } \\
\text { Kamera }\end{array}$ & $\begin{array}{c}\text { Ukuran } \\
\text { Layar }\end{array}$ & $\begin{array}{c}\text { OS } \\
\text { Android }\end{array}$ \\
\hline Oppo Miror 5 & \begin{tabular}{|l|} 
Qualcomm \\
MSM8916 \\
Snapdragon \\
410
\end{tabular} & $2 \mathrm{~GB}$ & $5 \mathrm{MP}$ & 5,0 inci & $\begin{array}{l}\text { Android } \\
5.1 \\
\text { (Lollipop) }\end{array}$ \\
\hline OPPO A83 & $\begin{array}{l}\text { Mediatek } \\
\text { MT6763T } \\
\text { Helio P23 }\end{array}$ & $2 \mathrm{~GB}$ & $13 \mathrm{MP}$ & 5.7 Inch & \begin{tabular}{|l} 
Android \\
7.1 \\
(Nougat)
\end{tabular} \\
\hline $\begin{array}{ll}\text { ZenFone } & 4 \\
\text { Max } & \end{array}$ & \begin{tabular}{|l} 
Qualcomm® \\
Snapdragon \\
TM 425
\end{tabular} & $3 \mathrm{~GB}$ & $13 \mathrm{MP}$ & 5.2-inci & \begin{tabular}{|l} 
Android 7.0 \\
(Nougat)
\end{tabular} \\
\hline Realme 3 Pro & \begin{tabular}{|l|} 
Qualcomm \\
Snapdragon \\
710 AlE
\end{tabular} & $4 \mathrm{~GB}$ & $16 \mathrm{MP}$ & 6.3 inci & $\begin{array}{l}\text { Android } 9.0 \\
\text { (Pie) }\end{array}$ \\
\hline
\end{tabular}

\begin{tabular}{|c|l|l|l|l|}
\hline $\begin{array}{c}\text { Perangkat } \\
\text { Smartphone }\end{array}$ & \multicolumn{1}{|c|}{$\mathbf{1}$} & $\mathbf{2}$ & $\mathbf{3}$ & $\mathbf{4}$ \\
\hline $\begin{array}{c}\text { Buka } \\
\text { aplikasi }\end{array}$ & 12 detik & 10 detik & 13 detik & 11 detik \\
\hline $\begin{array}{c}\text { Masuk menu } \\
\text { AR Kamera }\end{array}$ & 7 detik & 10 detik & 6 detik & 3 detik \\
\hline $\begin{array}{c}\text { Masuk ke } \\
\text { informasi }\end{array}$ & 1 detik & 1 detik & 1 detik & 1 detik \\
\hline $\begin{array}{c}\text { Masuk ke } \\
\text { petunjuk }\end{array}$ & 1 detik & 1 detik & 1 detik & 1 detik \\
\hline $\begin{array}{c}\text { Scan marker } \\
\text { Jarak } \\
\text { maksimal }\end{array}$ & $10 \mathrm{detik}$ & 2 detik & 1 detik & 1 detik \\
\hline $\begin{array}{c}\text { Kembali ke } \\
\text { menu utama }\end{array}$ & 1 detik & 1 detik & 1 detik & 1 detik \\
\hline $\begin{array}{c}\text { Keluar } \\
\text { aplikasi }\end{array}$ & 2 detik & 2 detik & 1 detik & 1 detik \\
\hline
\end{tabular}

Bersumber pada hasil pengujian semacam diarahkan pada table di atas, nampak kalau secara kesekian bisa disimpulkan kalau aplikasi pembelajaran ini bisa di instalasi pada seluruh fitur handphone. Perbedaan- perbedaan yang terjalin pada kecepatan proses aplikasi ini terjalin sebab perbandingan unit prosesor serta RAM pada masing- masing fitur mempunyai tingkatan yg berbeda. Perbandingan terpotongnya sedikit tombol pada UI pula diakibatkan sebab perbandingan dimensi layar pada masing- masing fitur. Tidak hanya itu pada guna audio, kejernihan foto, kejelasan objek 3D serta kelengkapan tampilan berjalan dengan baik.

a) Hasil terbaik untuk Camera proses terdapat pada perangkat Realme 3 Pro dengan spesifikasi Qualcomm Snapdragon 710 AIE, Ram 4GB, Android 9.0 (Pie)

b) Hasil terbaik untuk proses aplikasi terdapat pada perangkat ZenFone 4 Max dengan spesifikasi

Qualcomm ${ }^{\circledR}$ Snapdragon ${ }^{\mathrm{TM}} 425$, Ram 3GB, Android 7.0 (Nougat)

\section{KESIMPULAN DAN SARAN}

Beberapa hal yang dapat dikembangkan dari aplikasi ini diantaranya :

a) Fitur pada aplikasi hallo gigi masih dapat ditambahkan agar lebih interaktif lagi, seperti menambah 3D, mini games, ataupun video dan artikel informasi yang lebih luas.

b) Materi dan konten pada alikasi ini masih dapat dikembangkan dan diperbanyak lagi, masih banyak materi dari kesehatan gigi yang dapat dimasukkan dalam bentuk video, teks ataupun gambar.

\section{DAFTAR PUSTAKA}

[1] Abdurakhman. (2005). Teori Belajar dan Pembelajaran ISSN : 2550-0252. Pendidikan Guru Sekolah Dasar,Vol.02 No.01,Universitas Djuanda.

[2] Artsiyanti, D. E. (2002). Alphabet Bahasa Inggris ISSN 1858-4543,Vol.01 No.02. Universitas Gunadarma.

[3] Candra, A. R. (2014). Perancangan Mobile Augmented Reality System Untuk Wisata Sejarah. SENARAI,p 211213,Unuiversitas Muhammadiyah Ponorogo

[4] Hanafy, M. S. ( 2014). Konsep Belajar dan Pembelajaran. Pendidikan dan Pembelajaran Vol.17 No.01 ISSN-25495801,Universitas Islam Negeri Alaudin Makasar.

[5] Manalu, M. R. (2015). Implementasi Sistem informasi ISSN :2088-3943. Vol.18 No.02 Teknologi informasi, Politeknik Trijaya Krama Medan.

[6] Muhammad, A. (2019). Implementasi Model Pembelajaran Sentra di TK Amal Insani ISSN: 2502-3519. Teori Belajar,Universitas Islam Negeri Sunan Kalijaga

[7] Salpariansi, Erwin. METODE PEMBELAJARAN MEMBACA DAN MENULIS PERMULAAN DI KELAS AWAL,Vo.04, No.1, ISSN 2540-9093, Universitas Sultan Ageng Tirtayasa.

[8] Sariyun. (2015). Perancangan Dan Implementasi Aplikasi Mobile Semarang Guidance Pada Android. Jurnal Teknologi Informasi DINAMIK,Vol.20 No.01,ISSN : 0854-9524, p 149-151, Universitas Stikubank Semarang

[9] Sujarnoto. (2015). PERANCANGAN ALAT PERAGA ALFABET SEBAGAI PENGENALAN HURUF KEPADA ANAK-ANAK. Imajinasi Seni Dan Pendidikan Seni, 07-08, Universitas Negeri Padang

\section{BIODATA PENULIS}

\section{Adam Rizki Fadhlurahman}

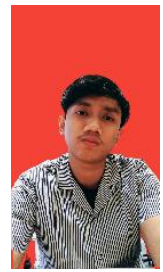

Adam Rizki merupakan mahasiswa tingkat akhir Multimedia Politeknik Negeri Media Kreatif Jakarta angkatan 2017. Lahir di Depok 15 Januari 2000 dan bertempat tinggal di Jakarta. Memiliki hobi membaca, basket, berenang. 